\title{
ANALISIS KEMAMPUAN GURU DALAM PERENCANAAN PEMBELAJARAN PPKn PADA TATAP MUKA MASA PANDEMI COVID-19 DI SMPN 2 RANTEPAO
}

\author{
1Emi Liku, ${ }^{2}$ Mesta Limbong, ${ }^{3}$ Witarsa Tambunan \\ 1,2,3 Magister Administrasi Pendidikan PPs-UKI, Jakarta, Indonesia \\ e-mail: witarsa.oke@gmail.com, mestalimbong@uki.ac.id
}

\begin{tabular}{l|l|l} 
Received : Mei, 2021 & Accepted : Mei, 2021 & Published : Juli, 2021
\end{tabular}

\begin{abstract}
This study aims to improve the ability of teachers in lesson planning and PPKn face-to-face during the COVID-19 pandemic at SMPN 2 Rantepao and improve student achievement outcomes. The research subject is a PPKn subject teacher. The research methodology used is descriptive qualitative approach with literature review and problem tree, hope tree, alternative/solution tree. Data collection techniques, using interviews and observation. The results of the study showed the low ability of teachers in making civics learning plans during the covid-19 pandemic. There are obstacles faced by teachers in planning Civics learning, namely the lack of determining learning objectives, selecting appropriate methods, techniques and learning media. From the results of this study, it is recommended that It is recommended that the SMPN 2 Rantepao school in improving student achievement and achieving good Civics learning planning, it is necessary: 1) Conduct training on the use of good learning methods and media according to the covid-19 curriculum, 2) Conduct socialization of the Covid-19 emergency curriculum, 3) Improve teacher competence through the Subject Teacher Conference.
\end{abstract}

Keywords: teacher ability, PPKn learning planning, face to face, covid 19 pandemic

\begin{abstract}
Abstrak
Penelitian ini bertujuan meningkatkan kemampuan guru dalam perencanaan pembelajaran dan PPKn pada tatap muka masa pandemi covid-19 di SMPN 2 Rantepao dan meningkatkan hasil prestasi siswa. Subjek penelitiannnya adalah guru mapel PPKn. Metodologi penelitian yang digunakan adalah kualitatif deskriptif dengan pendekatan literartur review dan pohon masalah,pohon harapan,Pohon alternatif/solusi. Teknik pengumpulan data, menggunakan wawancara dan observasi. Hasil penelitian didapatkan rendahnya kemampuan guru dalam membuat perencannaan pembelajaran PPKn pada masa pandemi covid-19. Adanya kendala yang dihadapi guru dalam perencanaan pembelajaran PPKn yaitu kurangnya penentuan tujuan pembelajaran, pemilihan metode,teknikteknik dan media belajar yang tepat. Dari hasil penelitian ini disarankan sebaiknya. Sebaiknya pihak sekolah SMPN 2 Rantepao dalam meningkatkan prestasi siswa dan tercapainnya perencanaan pembelajaran PPKn yang baik maka perlu ;1)Mengadakan pelatihan penggunaan metode dan media pembelajaran yang baik sesuai kurikulum covid-19,2)Mengadakan sosialisasi kurikulum darurat covid-19,3)Peningkatan kompetensi guru melalui Musyawarah Guru Mata pelajaran
\end{abstract}


Kata Kunci: kemampuan guru, perencanaan pembelajaran PPKn, tatap muka, pandemi covid 19

Citation: Liku, E., Limbong, M., \& Tambunan, W. (2021). ANALISIS KEMAMPUAN GURU DALAM PERENCANAAN PEMBELAJARAN PPKn PADA TATAP MUKA MASA PANDEMI COVID-19 DI SMPN 2 RANTEPAO. Jurnal Manajemen Pendidikan, 10(2), 91-99. Retrieved from http://ejournal.uki.ac.id/index.php/imp/article/view/3273

\section{PENDAHULUAN}

Pandemi covid-19 menjadi masa dimana wabah virus covid-19 mereba dari bulan maret tahun 2020 sampai sekarang masih berlangsung. Banyak dampak yang di akibatkan dari wabah virus covid-19, dimana banyak yang terkonfirmasi yang mengakibatkan kematian di seluruh dunia karena wabah tersebut, termasuk pada sector pendidikan terjadi perubahan sistem pembelajaran. Belajar secara online dilakukan sebagai cara untuk melangsungkan pendidikan di tengah pandemi. Perubahan pembelajaran tatap muka ke online di mana siswa belajar dari rumah dan guru pun mengajar dari rumah. Perubahan sistem pendidkan sangat cepat dirasakan di seluruh dunia namun menghadapi kendala dalam proses pembelajran utamanya dirasakan oleh guru dan siswa. Tidak ada interaksi yang baik sehingga berdampak pada mutu pendidikan.

Pemerintah dalam menyikapi masalah tersebut memberikan kelonggaran pada satuan pendidikan untuk melakukan tatap muka dengan tetap melaksanakan protocol kesehatan melalui kebijakan belajar lewat surat keputusan empat menteri tentang panduan penyelenggaraan pembelajaran tatap muka dimasa pandemi yang berada pada wilayah zona hijau. SMPN 2 Rantepao telah melaksanakan tatap muka sejak minggu kedua bulan juli tahun 2020. Pelaksanaan pembelajran tatap muka dilakukan dengan sistem shif pembagian waktu disetiap tingkatan kelas. setiap kelas hanya ada 16 sampai 18 siswa pada setiap shif. Pembagian waktu untuk setiap shif berlangsung 45 menit pada setiap jam mata pelajaran. Dalam satu hari hanya ada dua kali shif tatap muka per tingkatan. Jadwal tatap muka dalam satu minggu berlangsung dalam 3 hari untuk setiap tingkatan kelas VII, VIII, IX. Dalam pembelajaran tatap muka di masa pandemi kendala yang dihadapi adalah kurangnya kemampuan guru dalam merencanakan pembelajaran Pendidkan Pancasila dan Kewarganegaraan (PPKn) dengan durasi waktu yang pendek khususnya dalam pemilihan tujuan, metode, teknik-teknik dan media pembelajaran yang sesuai sehingga mengakibatkan siswa kurang memahami pelajaran yang diterima pada proses pembelajaran pada tatap muka masa pandemi covid-19. Guru dan pendidik sebagai elemen penting dalam pengajaran diharuskan melakukan migrasi besar-besaran yang belum pernah terjadi sebelumya dari pendidikan tatap muka tradisional ke pendidikan online atau pendidikan jarak jauh (Bao, 2020; Basilaia \& Kvavadze, 2020).

Maka diharapkan kemampuan seorang guru dalam membuat perencanaan pembelajaran sesuai kondisi pandemi covid-19. Pembelajaran merupakan kegiatan inti dalam proses pendidikan, karena melalui kegiatan belajar ini diharapkan dapat dicapai tujuan pendidikan dalam bentuk terjadinya perubahan tingkah laku dalam diri siswa, juga menjadi harapan semua pihak agar setiap siswa mencapai hasil belajar yang sebaik-baiknya sesuai dengan kemampuan masing-masing. Menurut Wina Sanjaya dalam (Ananda, R., \& Amiruddin, A. (2019).menjelaskan bahwa perencanaan pembelajaran adalah proses pengambilan keputusan hasil berpikir secara rasional tentang sasaran dan tujuan pembelajaran tertentu, yakni perubahan perilaku serta rangkaian kegiatan yang harus dilaksanakan sebagai upaya pencapaian tujuan tersebut dengan memanfaatkan segala potensi dan sumber belajar yang ada. Dengan memperhatikan kondisi-kondisi real yang ada di SMPN 2 Rantepao, salah satu langkah yang tepat dilakukan pihak sekolah adalah Melakukan penelitian terhadap kemampuan guru dalam perencanaan pembelajaran PPKn pada tatap muka masa pandemi covid-19 


\section{Kemampuan Guru}

Menurut Gordon dalam (Mulyasa, 2005:38-39), ada enam aspek atau ranah yang terkandung dalam konsep kompetensi, yaitu : (1) pengetahuan (knowledge), yaitu kesadaran dalam bidang kognitif, (2) pemahaman (under-standing), yaitu kedalaman kognitif dan afektif yang dimiliki individu, (3) kemampuan (skill), sesuatu yang dimiliki individu untuk melakukan tugas atau pekerjaan yang dibebankan kepadanya, (4) nilai (value), suatu standar perilaku yang telah diyakini dan secara psikologis telah menyatu dalam diri seseorang, (5) sikap (attitude), perasaan (senang - tidak senang, suka - tidak suka) atau reaksi terhadap suatu rangsangan yang datang dari luar, dan (6) minat (interest), yaitu kecenderungan seseorang untuk melakukan sesuatu. Menurut asal katanya, "competency" berarti kemampuan atau kecakapan. Kompetensi juga diartikan "... the state of being legally competent or qualified", yaitu keadaan berwewenang atau memenuhi syarat menurut ketentuan hukum. Arti kompetensi guru adalah "the ability of a teacher to responsibly perform his or her duties appropriately", artinya kemampuan seorang guru dalam melaksanakan kewajibannya secara bertanggungjawab dan layak (Muhibbin Syah, 2004 : 229).

Menurut Depdiknas, kompetensi adalah pengetahuan, keterampilan, dan nilai-nilai dasar yang direfleksikan dalam kebiasaan berpikir dan bertindak. Arti lainnya, kompetensi adalah spesifikasi dari pengetahuan, keterampilan, dan sikap yang dimiliki seseorang serta penerapannya di dalam pekerjaan, sesuai dengan kinerja yang dibutuhkan lapangan (Depdiknas, 2004:3-4). Dengan demikian, kompetensi yang dimiliki setiap guru akan menunjukkan kualitas guru yang sebenarnya. Kompetensi tersebut akan terwujud dalam bentuk penguasaan pengetahuan, keterampilan, maupun sikap profesional dalam menjalankan fungsi sebagai guru.

Pengertian lain dikemukakan oleh Mulyasa (2005:37-38), yaitu kompetensi merupakan perpaduan dari pengetahuan, keterampilan, nilai, dan sikap yang direfleksikan dalam kebiasaan berpikir dan bertindak. Menurut Anderson S \& Ball S (1978 :3), kompetensi guru adalah himpunan pengetahuan, kemampuan, dan keyakinan yang dimiliki seorang guru dan ditampilkan dalam situasi mengajar. Berdasarkan pendapat dari beberapa pendapat ahli di atas dapat disintesakan bahwa "Kemampuan guru adalah adanya pengetahuan dan keterampilan yang dimiliki oleh seorang guru dengan menunjukkan nilai,sikap dalam berpikir dan bertindak melaksankan tupoksinya".

\section{Perencanaan Pembelajaran}

Perencanaan berasal dari kata rencana yaitu pengambilan keputusan tentang apa yang harus dilakukan untuk mencapai tujuan. Dengan demikian, proses suatu perencanaan harus dimulai dari penetapan tujuan yang akan dicapai melalui analisis kebutuhan serat dokumen yang lengkap, kemudian menetapkan langkah-langkah yang harus dilakukan untuk mencapai tujuan tersebut.Ely (1979), mengatakan bahwa perencanaan itu pada dasarnya adalah suatu proses dan cara berfikir yang dapat membantu menciptakan hasil yang diharapkan. Kaufman (1972) memandang bahwa perencanaan itu adalah sebagai suatu proses untuk menetapkan "kemana harus pergi" dan bagaimana untuk sampai ke "tempat" itu dengan cara yang paling efektif dan efisien. Terry (1993) mengungkapkan bahwa perencaaan itu pada dasarnya adalah penetapan pekerjaan yang harus dilaksanakan oleh kelompok untuk mencapai tujuan yang telah ditentukan. Menurut William $\mathrm{H}$. Newman dalam bukunya Administrative Action Techniques of Organization and Mangement: mengemukakan bahwa "perencanaan adalah menentukan apa yang akan dilakukan.

Perencanaan mengandung rangkaian-rangkaian putusanyang luas dan penjelasan-penjelasan dari tujuan, penentuan kebijakan, penentuan program, penentuan metode-metode dan prosedur tertentu dan penentuan kegiatan berdasarkan jadwal sehari-hari.Pengertian tentang perencanaan pembelajaran dikemukakan oleh Nana Sudjana (1998, 2000:61) yang mengemukakan bahwa perencanaan pembelajaran adalah kegiatan memproyeksikan tindakan apa yang akan dilaksanakan dalam suatu pembelajaran (PBM) yaitu dengan mengkoordinasikan (mengatur dan merespon) komponen-komponen pembelajaraan, sehingga arah kegiatan (tujuan ), isi kegiatan (materi) , cara penyampaaian kegiatan ( metode dan teknik ) serta bagaimana mengukurnya (evaluasi) menjadi 
jelas dan sistematis?. Ini berarti perencanaan pembelajaran pada dasarnya mengatur dan menetapkan komponen-komponen tujuan, bahan, metode atau teknik, serta evaluasi atau penilaian. Menurut Bunghart dan Trull dalam ( Sagala : 2003) menyatakan bahwa ?Perencanaan adalah awal dari semua proses yang rasional, daan mengandung sifat optimisme yang didasarkan atas kepercayaan bahwa akan dapat mengatasi berbagai macam permasalahan dalam konteks pembelajaran. Perencanaan pembelajaraan yang diartikan sebagai proses penyusunan materi pelajaran, penggunaan media pembelajaran, pengunaan pendekatan atau metode pembelajaran, dalam suatu alokasi waktu yang akan dilaksanakan pada masa satu semester yang akan datang untuk mencapai tujuan yang ditentukan. Berdasarkan PP No. 19 Tahun 2005 Pasal 20 dinyatakan bahwa: Perencanaan proses pembelajaran meliputi silabus dan rencana pelaksanaan pembelajaran yang memuat sekurang-kurangnya tujuan pembelajaran, materi ajar, metode pengajaran, sumber belajar, dan penilaian hasil belajar. Berdasarkan pendapat para ahli di atas dapat disintesakan bahwa perencanaan pembelajaran adalah"Proses merangcang ,menyusun,menetapkan komponenkomponen bahan pembelajaran dan kegiatan yang akan dilakukan sehubungan pembelajaran secara efektif dan efisien.

\section{Tatap Muka}

Menurut Ahamer, (2010:103).Pada awalnya, pembelajaran hanya dilakukan secara tatap muka. Pengajaran terjadi secara tatap muka karena pada awalnya tidak terdapat administrasipendukung untuk melakukan pengajaran jarak jauh (Ahamer, 2010:103) menjelaskan bahwa".Pembelajaran tatap muka adalah terjadinya interaksi pembelajaran yang dilakukanoleh pendidik dan peserta didik pada waktu dan tempat yang sama. Pembelajaran tatap muka disebut juga dengan pembelajaran tradisional."

Pandemi Covid -19

Menurut KBBI menjelaskan bahwa" Pandemi dimaknai sebagai wabah yang berjangkit serempak di mana-mana meliputi daerah geografi yang luas"

virus Covid-19 adalah senjata biologi yang dibuat manusia di sebuah lab dan perusahaan farmasi (tertentu) telah mencoba memblokir berbagai pengobatan tradisional demi mempromosikan obat dan vaksin yang berbahaya"

\section{METODE PENELITIAN}

Metodologi yang digunakan dalam penelitian ini adalah kualititatif deskriptif dengan pendekatan literature review dan teknik pengumpulan data lewat wawancara dan observasi terhadap guru PPKn di SMP 2 Rantepao. Pemeriksaan keabsahan data menggunakanttriangulasi teknik dan triangulasi sumber. Teknik analisis data reduksi data, penyajian data, dantpenarikan kesimpulan.Tujuan dari penelitian ini adalah untuk mengetahui kemampuan guru dalam perencanaan pembelajaran PPKn dalam pemilihan tujuan, metode, teknik-teknik serta media tepat dalam proses pembelajaran pada tatap muka di masa pandemi covid-19. Hasil dari penelitian ini diharapkan dapat memotivasi guru PPKn untuk membuat perencanaan pembelajaran yang tepat sesuai kondisi yang terjadi. Penelitian ini merupakan hasil data yang diambil dapat berupa hasil wawancara dan observasi pada saat supervisi kelas dan dikomfirmasi dengan respon siswa untuk mendapatkan hasil yang maksimal.

\section{HASIL DAN PEMBAHASAN}

Kemampuan Guru.

Kemampuan dan kewanangan guru mengacu pada kemampuan melaksanakan sesuatu yang diperoleh melalui pendidkan ,kompetensi,merujuk kepada performance dan perbuatan untuk memenuhi verifikasi tertentu di dalam pelaksanaan tugas-tugas kependidikan menurut (Hawi, 2010) dalam (Sulfemi, W. B. (2019).Kemampuan guru dalam hal ini mengisyaratkan bahwa guru 
harus benar-benar memperhatikan aspek tertentu dalam merumuskan tujuan pembelajaran sesuai prosedur yang telah ditentukan. Kemanpuan guru dalam proses pembelajaran dalm menyiapkan perencanaan pembelajaran akan berdampak pada peningkatan prestasi siswa dan mutu pendidikan akan menjadi lebih baik.Siswa sangat merespon pemebelajaran apabila guru mampu merencanakan pembalajaran dengan pemilihan tujuan pembelajaran yang sesuai,metode,teknik-teknik serta media pembelajaran yang digunakan dapat merespon siswa lebih mudah menerima pembelajaran.

Dari hasil penelitian lewat wawancara dan observasi pada guru PPKn yang ada di SMPN 2 Rantepao pada saat supervisi kelas di tahun ajaran 2020/2021 semester genap sebanyak tiga orang guru didapatkan kurang mampu merencanakan pembelajaran dalam menentukan tujuan pembelajaran yang sesuai,metode, teknik-teknik dan media pembelajaran yang tepat digunakan ketika melaksanakan proses pembelajaran di kelas.Kurangnya respon dari siswa serta tidak adanya interaksi menyebabkan kegagalan dalam proses pembelajaran,sehingga siswa mengalami kesulitan dalam belajar ketika tatap muka di masa pandemi mulai dilaksanakan dalam durasi waktu yang singkat. Kendala yang dihadapi guru PPKn SMPN 2 Rantepao perlu mendapatkan perhatian serta motivasi dari pihak sekolah untuk meningkatkan kemampuan guru lewat kegiatan pelatihan, serta pengalaman lewat jenjang pendidikan yang dapat menambah pengetahuan dan keterampilan .

Perencanaan Pembelajaran

Menurut Nana Sudjana dalam (2018:Juli).)menjelaskan bahwa "perencanaan pembelajaran adalah kegiatan memproyeksikan tindakan apa yang akan dilaksanakan dalam suatu pembelajaran, yaitu dengan mengkoordinasikan (mengatur dan merespon) komponen-komponen pembelajaran sehingga arah kegiatan (tujuan), isi kegiatan (materi), cara penyampaian kegiatan (metode dan teknik), serta bagaiman mengukurnya (evaluasi) menjadi jelas dan sistematis. Sebelum melakukan pembelajaran dalam kelas, guru harus mempersiapkan perencanaan pembelajaran terlebih dahulu. Dalam mempersiapkan rencana pembelajaran guru harus memiliki kemampuan 4C yaitu communication,tcollaborative, critical thinking and problem solving, dan creativity and innovation. Biasa juga dikenal dengan keterampilan abad 21. Dalam perencanaan pembelajaran guru harus mengkaitkan 4 keterampilan tersebut agartpembelajaran berjalan dengan efektif dan efisien. Berbagai keterampilan sosial dan keterampilan komunikasi juga dibutuhkan, termasuk kemampuan untuk berkolaborasi dengan orang lain (Laddtet al., 2014; Ouellet, Sabbagh, Bergeron, Mayer, \& St-Onge, 2016). Sebelum melaksanakan kegiatan belajar mengajar.

Penentuan Tujuan pembelajaran membantu dalam mendesain sistem pembelajaran. Artinya, dengan tujuan yang jelas dapat membantu guru dalam menentukan materi pelajaran, metode atau strategi pembelajaran, alat, media dan sumber belajar, serta dalam menentukan dan merancang alat evaluasi untuk melihat keberhasilan belajar siswa. Selain itu, tujuan pembelajaran juga dapat digunakan sebagai kontrol dalam menentukan batas-batas dan kualitas pembelajaran. Artinya, melalui penetapan tujuan, guru dapat mengontrol sampai mana siswa telah menguasai kemampuan-kemampuan sesuai dengan tujuan dan tuntutan kurikulum yang berlaku. Lebih jauh dengan tujuan dapat ditentukan daya serap siswa dan kualitas suatu sekolah. Penggunaan Metode dalam perencanaan pembelajaran akan memberi kemudahan bagi guru untuk memberi cara atau strategi untuk memahami materi kepada siswa sesuai dengan tujuan pembelajaran yang telah ditentukan.Menurut Trianto (2010) dalam Nasution, M. K. (2018)menjelaskan bahwa "Metode pembelajaran sangat dibutuhkan dalam sekolah, khususnya bagi pembelajaran di dalam kelas. model pembelajaran adalah suatu perencanaan atau pola yang digunakan sebagai pedoman dalam merencanakan pembelajaran di kelas atau pembelajaran tutorial. Sedangkan Pupuh dan Sobry S (2010) dalam Nasution, M. K. (2018) juga berpendapat makin tepat metode yang digunakan oleh guru dalam mengajar, diharapkan makin efektif pula pencapaian tujuan pembelajaran dan menurut T. Raka Joni (dalam Abimanyu, 2008) menjelaskan bahwa "Teknik pembelajaran menunjuk kepada ragam khas penerapan sesuatu metode dengan latar tertentu, seperti kemampuan dan kebiasaan guru, ketersediaan peralatan, kesiapan siswa dan sebagainya." Teknik pembelajaran dapat membantu guru dalam perencanaan pembelajaran khususnya dalam pembunatan rancangan perangkat pembelajaran. 
Menurut Depertemen Pendidikan dan kebudayann dalam Jamil (2016: 154), metode adalah cara kerja yang bersistem untuk memudahkan pelaksanaan suatu kegiatan guna mencapai tujuan yang ditentukan. Berdasarkan etimologinya, metode pada dasarnya merupakan cara yang digunakan dalam proses pendidikan yang bertujuan untuk mempermudah pencapaian tujuan pendidikan yang diinginkan. Penggunaan media dan alat peraga sangat dibutuhkan untuk proses kegiatan belajar mengajar siswa. Maka dari itu dalam merumuskan rencana pembelajaran guru harus mengetahui media apa yang digunakan sesuai dengan materi yang diajarkan. Hal tersebut memudahkan guru untuk mengetahui bahwa ketersediaan media dan alat peraga di sekolah ada atau tidak. . Jika contoh media dan alat peraga belum ada, maka guru harus membuat, mencari, atau membeli alat peraga dengan cacatan alat peraga tersebut termasuk golongan yang mudah dijangkau. Seperti yang terurai tpada Undang-Undang No.20 Tahun 2003 Tentang Sistem Pendidikan Nasional Bab XI pasal 40, bahwa tenaga kependidikan berhak mendapatkant kesempatan untuk menggunakan fasilitas, sarana, dan prasarana pendidikan untuk menunjang kelancarantpelaksanaan tugas mengajar. Keberhasilan prosest pembelajaran ditentukan oleh proses tperencanaan, guru harus dituntut untuk membuat perencanaan pembelajaran yang baik. Menurut Martiyono (2012: 240) mengemukakan bahwa pembelajaran yang berkualitas ditentukan oleh perencanaan pembelajarantyang mantap dan bagus, maka dari itu guru harustmerencanakan pembelajarantyang tepat.

Dalam penelitian ini ditemukan permasalahan yang dihadapi oleh keempat guru PPKn di SMPN 2 Rantepao yang menjadi informan .Kendala yang dihadapi selama pembukaan Tatap muka di masa pandemi covid-19 di awal bulan Juli tahun 2020 ,khususnya dalam perencanaan pembelajaran untuk pembuatan rancangan perangkat pembelajaran merdeka Belajar .Didapatkan kurang mampunnya guru PPKn tersebut dalam menentukan tujuan pembelajaran yang esensial sesuai kondisi waktu yang singkat dalam proses pembelajaran ,begitupun dalam pemilihan metode dan media belajar,sehingga pembelajaran kurang efektif dan efisien dirasakan oleh guru karena keterbatasan pendidikan, pengalaman dan kurang mengikuti pelatihan-pelatihan teknik -teknik pembuatan perencanaan pembelajaran. Dari pembahasan tersebut di atas, penulis menaruh harapan sekirannya pihak sekolah SMPN 2 Rantepao perlu meningkatkan kemampuan guru dalam perencanaan pembelajaran PPKn khususnya penentuan tujuan pembelajaran,pemilihan metode pembelajaran dan media yang tepat dalam perencanaan pembelajaran oleh guru yang akan memberi dampak pada peningkatan mutu pendidikan dan prestasi siswa dalam belajar pada masa pandemi covid-19.Peningkatan kemampuan guru PPKn bisa dilakukan dengan memberikan pelatihan -pelatihan teknik perencanaan pembelajaran yang efektif dan efisien,meningkatkan pengalaman lewat pendidikan dan penguasaan kurikulum yang berlaku.

\section{Tatap Muka}

Pada awalnya, pembelajaran hanya dilakukan secara tatap muka. Pengajaran terjadi secara tatap muka karena pada awalnya tidak terdapat administrasi pendukung untuk melakukan pengajaran jarak jauh (Ahamer, 2010:103). Pembelajaran tatap muka adalah terjadinya interaksi pembelajaran yang dilakukan oleh pendidik dan peserta didik pada waktu dan tempat yang sama. Pembelajaran tatap muka disebut juga dengan pembelajaran tradisional. Seiring dengan perkembangan teknologi informasi, proses pembelajaran juga mengalami perubahan. Proses pembelajaran yang awalnya hanya tatap muka, berkembang dengan adanya pembelajaran online. Kondisi pandemi covid -19 merubah transformasi proses pendidikan di seluruh dunia menjadi cepat karena adannya mewabahnya virus covid-19 tersebut.Dari pembelajaran tatap muka sebelum pandemi berubah menjadi pembelajaran online.Di Indonesia pun menjadi dampak dari pandemi covid-19,dimana proses pembelajaran dilaksanakan di rumah oleh guru dan siswa.Pemberlakuan social distancing disetiap wilayah Indonesia pun berbeda-beda,karena tidak semua wilayah terkonfirmasi covid19.Kebijakan pelaksanaan pembelajaran oleh Kemdikbud dilaksanakan sesuai informasi dari satuan gugus depan (SATGAS) disetiap daerah sesuai penentuan kategori zona yang berlaku .Kabupaten Toraja Utara ,dimana sekolah SMPN 2 Rantepao berada ,termasuk dalam kategori zona hijau dalam arti masih kondisi yang aman. 
Dalam pelaksanaan tatap muka di SMPN 2 Rantepao ,tentunya tidak sebaik waktu sebelum normal,karena kendala waktu yang singkat hanya 45 menit untuk setiap mata pelajaran. Kegiatan pembelajaran tatap muka tetap berlangsung normal meski ketersediaan waktu yang terbatas sesuai dengan aturan dari pemerintah. Hal ini juga yang membuat guru PPKn terkendala dalam merencanakan pembelajaran secara efektif dan efisien.Dibutuhkan kemampuan dari setiap guru untuk merancang pembelajaran sesuai kondisi waktu yang ada,sehingga protocol kesehatan tetap terjaga.Guru diharapkan meningkatkan kemampuan ,keterampilan dalam merencanakan pembelajaran sesuai kondisi yang terjadi ,sehingga siswa dapat meraih prestasi dengan baik.

Pandemi Covid-19

Menurut (P. Ayu Suci \& Gunawan, 2020)(Siahaan, 2020)(Syah, 2020).dalam (Nissa, S. F., \& Haryanto, A. (2020) menjelaskan pernyataannya bahwa"Wabah Coronavirus2019 (Covid-19) sangat mengguncang masyarakat dunia.Menurut World Health Organitazation (WHO),hingga saat ini terkonfirmasi 200 Negara di Dunia terjangkit wabah Covid-19 termasukIndonesia. "Hampir seluruh sektor kehidupan terkena dampakdari wabah Covid-19, tidak terkecuali di sektor .. pendidikan. Pada satuan pendidikan yang berada di zona hijau, dapat melaksanakan pembelajaran tatap muka dengan tetap memperhatikan protokol Kesehatan.Salahsatu wilayah yang melaksanakan pembelajaran tatap muka adalah kabupaten tegal. Covid-19 adalah penyakitjenis baru yang belum pernah diidentifikasi sebelumnya pada manusia(Fauci et al., 2020)dalam (Nissa, S. F., \& Haryanto, A. (2020). Penyakit ini pertama kali ditemukan pada Desember 2019 di Wuhan, Ibukota Provinsi Hubei China, dan sejak saat itu menyebar secara global. Organisasi Kesehatan Dunia (WHO) mendeklarasikan wabah coronavirus2019 sebagai Kesehatan Masyarakat Darurat Internasional (PHEIC) pada 30 Januari 2020.Tanda dan gelaja umum infeksiCOVID-19 antara lain gejala gangguan pernapasan akut, seperti demam, batuk, dan sesak napas(Handayani et al., 2019)..Berbagai upaya pencegahan penyebaran virus Covid-19 pun dilakukan oleh pemerintah Indonesia,

Pandemi Covid -19 bukanlah situasi yang menjadi tantangan untuk terus membangun mutu pendidikan di Indonesia.Namun dengan kondisi pandemi menjadi cambuk bagi dunia pendidikan untuk terus berbenah dalam meningkatkan mutu pendidikan di Indonesia. Proses pembelajaran dalam masa pandemi covid -19 tidak selancar waktu sebelum keadaan normal,banyak kendala yang dihadapi guru dan siswa dalam belajar,kurangnya persiapan dalam perencanaan pembelajaran, waktu tatap muka relative singkat.Hal ini juga menjadi kendala bagi guru mata pelajaran PPKn di SMPN 2 Rantepao dalam merencanakan pembelajaran.Kurangnya kemampuan guru dalam memilih tujuan pelajaran, pemiliha metode dan media pembelajaran yang sesuai dengan kondisi waktu tatap muka pada masa pandemi covid-19.

\section{KESIMPULAN}

Kesimpulan

Berdasarkan pembahasan yang diatas, dapat diambil kesimpulan sebagai berikut:

Terbukti meningkatnya prestasi siswa di Sekolah SMPN 2 Rantepao dikarenakan tercapainya perencanaan pembelajaran PPKn yang tepat,tercapainya pemilihan metode belajar yang tepat,serta tercapainya penguasaan kurikulum yang baik.

Implikasi

Terbukti meningkatnya prestasi siswa di Sekolah SPMN 2 Rantepao dikarenakan tercapainya perencanaan pembelajaran PPKn yang tepat,pemilihan metode belajar dan penguasaan kurikulum yang baik.

Saran-Saran

Berdasarkan hasil penelitian, peneliti mengajukan saran-saran sebagai berikut: 
Sebaiknya pihak sekolah SMPN 2 Rantepao dalam meningkatkan prestasi siswa dan tercapainnya perencanaan pembelajaran PPKn yang baik maka perlu: (1) Mengadakan pelatihan penggunaan metode dan media pembelajaran yang baik sesuai kurikulum covid-19. (2) Mengadakan sosialisasi kurikulum darurat covid-19. (3) Peningkatan kompetensi guru melalui Musyawarah Guru Mata pelajaran

\section{DAFTAR PUSTAKA}

1. Ananda, R., \& Fadhilaturrahmi, F. (2018). Analisis Kemampuan Guru Sekolah Dasar dalam Implementasi Pembelajaran Tematik di SD. Jurnal Basicedu, 2(2), 11-21.

2. Ananda, R., 2019). Perencanaan Pembelajaran.

3. Astriyandi, A., Chotimah, U., \& Farian, E. E. (2016). KEMAMPUAN GURU MENERAPKAN PENILAIAN AUTENTIK DALAM PEMBELAJAAN PPKn (STUDI KASUS DI SMA NEGERI 1 INDRALAYA) (Doctoral dissertation, Sriwijaya University).

4. Dewanti, A. K. (2020). Perlindungan Terhadap Guru di Masa Pandemi. Arsip Publikasi Ilmiah Biro Administrasi Akademik.

5. Elfahmi, R. (2020). Upaya Peningkatan Kompetensi Guru Dalam Menerapkan Pembelajaran Daring Masa Pandemi Covid 19 di SMA Negeri 3 Seunagan. Bionatural: Jurnal Ilmiah Pendidikan Biologi, 7(2).

6. Fauziah, Y. N. (2011). Analisis kemampuan guru dalam mengembangkan keterampilan berpikir kreatif siswa Sekolah Dasar kelas V pada pembelajaran Ilmu Pengetahuan Alam. Jurnal Edisi Khusus, 1(1), 98-106.

7. Herliandry, L. D., Nurhasanah, N., Suban, M. E., \& Kuswanto, H. (2020). Pembelajaran pada masa pandemi covid-19. JTP-Jurnal Teknologi Pendidikan, 22(1), 65-70.

8. Jaya, F. (2019). Perencanaan Pembelajaran.

9. Lusiati, E. (2015). PENGARUH KEMAMPUAN GURU DALAM MEMBUAT RENCANA PELAKSANAAN PEMBELAJARAN TERHADAP MOTIVASI BELAJAR PKn SISWA KELAS X DI MAN 1 PONCOWATI TERBANGGI BESAR LAMPUNG TENGAH TAHUN PELAJARAN 2014/2015 (Doctoral dissertation, Fakultas Keguruan dan Ilmu Pendidikan).

10. Nasution, M. K. (2018). Penggunaan metode pembelajaran dalam peningkatan hasil belajar siswa. Studia Didaktika, 11(01), 9-16

11. Nissa, S. F., \& Haryanto, A. (2020). IMPLEMENTASI PEMBELAJARAN TATAP MUKA DI MASA PANDEMI COVID-19. Jurnal IKA PGSD (Ikatan Alumni PGSD) UNARS, 8(2), 402-409.

12. Prastyo, Z. (2015). gunung anyar Analisis kemampuan guru dalam pembuatan rpp kurikulum 2013 dan pembelajaran pendidikan jasmani kesehatan dan olahraga (pjok) se-kecamatan gununganyar kota surabaya (studi pada guru pjok sd negeri kelas iv semester genap sekecamatan kota surabaya). Jurnal Pendidikan Olahraga dan Kesehatan, 3(2).

13. Seles, R., Halidjah, S., \& Kresnadi, H. ANALISIS RENCANA PELAKSANAAN PEMBELARAN TEMATIK SECARA DARING SELAMA MASA PANDEMI COVID-19. Jurnal Pendidikan dan Pembelajaran Khatulistiwa, 10(3).

14. Sholeh, M. (2007). Perencanaan pembelajaran mata pelajaran geografi tingkat SMA dalam konteks KTSP. Jurnal Geografi: Media Informasi Pengembangan Dan Profesi Kegeografian, $4(2)$.

15. Sidauruk, V. A., \& Supeni, S. (2019). PERAN GURU DALAM PERENCANAAN, PELAKSANAAN DAN EVALUASI PEMBELAJARAN PPKN TERHADAP PEMBENTUKAN KARAKTER DISIPLIN SISWA KELAS X SMA NEGERI 6 SURAKARTA TAHUN PELAJARAN 2017-2018. Jurnal Global Citizen: Jurnal Ilmiah Kajian Pendidikan Kewarganegaraan, 6(2).

16. Siregar, N. (2019). Kemampuan guru dalam perencanaan pembelajaran pendidikan agama islam di MAN Barumun Tengah (Doctoral dissertation, IAIN Padangsidimpuan).

17. Sulfemi, W. B. (2019). Kemampuan pedagogik guru.

18. Tyas, R. A. (2020). Kemampuan Guru Dalam Perencanaan Pembelajaran Tematik Integratif Berbasis 4C Pada Siswa Kelas 5 SD Negeri Kedung Rembang Tahun Ajaran 2019/2020 (Doctoral dissertation, Universitas Muhammadiyah Surakarta).

19. Widyastuti, A., Sudarmanto, E., Silitonga, B. N., Ili, L., Purba, S. R. F., Khalik, M. F., ... \& Situmorang, K. (2021). Perencanaan Pembelajaran. Yayasan Kita Menulis. 
20. WILANDARI, H. (2020). ANALISIS KEMAMPUAN GURU DALAM MERANCANG PERENCANAAN PEMBELAJARAN TEMATIK BERDASARKAN KURIKULUM 2013 DI SD NEGERI 38 PAGAR ALAM (Doctoral dissertation, UIN RADEN FATAH PALEMBANG).

21. Yanti, A. Y. (2018, July). Kemampuan Guru dalam Merumuskan Tujuan Pembelajaran PPKN di Sekolah Menengah Kejuruan Negeri 1 Sukoharjo. In Prosiding Seminar Nasional (Vol. 7). 